\title{
THE IDEOLOGICAL AND REGULATORY QUESTIONS OF THE RIGHT TO PRIVACY, WITH PARTICULAR REGARD TO THE SITUATION OF PUBLIC FIGURES
}

Halász Csenge

\section{INTRODUCTION}

Defining and protecting the right to privacy is one of the important tasks of modern jurisdictions. The development of this right has always been greatly influenced by societal, economic and technological changes. The first drafting of this eligibility was brought forward when Eastman Kodak introduced a small, compact camera that made it possible to take photos clandestinely ${ }^{1}$. This gave a starting point to Samuel Warren's and Luis Brandeis' work that was published in the Harvard Law Review in December of 1890, titled "The Right to Privacy" which has laid the foundation of the discourse over privacy. As the authors wrote: "Recent inventions and business methods call attention to the next step which must be taken for the protection of the person".

Although, today the economic and societal system is completely different, the need for the protection of privacy, that Warren and Brandeis wrote about, has not expired, moreover, in some respect there is a greater need for protection than ever before. There is a stark contrast between this approach and the words of Mark Zuckerberg, founder of Facebook, from 2010 who stated that "privacy has ceased to be a social norm".

Emphasizing the importance of internet platforms, including social media sites, may seem superfluous in 2020, however, these sites' impact on rights relating to personality, in particular, on privacy, is unquestionable. The situation of public figures cannot be ignored in this matter, as the Civil Code does not provide an exact, universal legal definition for this group. The interpretation of this concept is, thus, a task for the judicial case-law.

In this study, I shall seek to explore that the right to privacy how and on what ideological basis fits in the domestic legal system, the development of this right's interpretation in relation to public figures, since the relationship between the public and private sphere is considered crucial in terms of every legal system. One of the cornerstones of a democratic legal system is

\footnotetext{
1 Peter Bertus-Barcza: Az első Kodak fényképezőgép. https://ng.hu/kultura/2006/09/04/ az_elso_kodak_fenykepezogep/ (Retrieved: 20 February 2020).

2 Simon Éva: Egy XIX. századi tanulmány margójára, 36.p. https://infonia.hu/digitalis folyoirat/2005_2/2005_2_simon_eva.pdf(Retrieved: 20 February 2020).
} 
the right to criticize legal entities engaged in public life, it also serves wideranging social discourse of this matter. In this respect, Act LIII of 2018 on the protection of privacy, concerning mainly the situation of public figures, is a judicial novelty.

In this analysis, after a necessary ideological systematization, I shall define the place of privacy in the Hungarian legal system, especially the innovations of the regulation. For this overview, I shall refer to the relevant case-law of the European Court of Human Rights. Along these main guidelines, I shall provide a more complex picture of the current situation of public figures' right to privacy, also I shall draw attention to possible anomalies.

\section{Some ideological questions about the right to privacy}

The ideological interpretation of the right to privacy poses several challenges. In this respect, it is important to note that the "private life" of public figures has always been observed differently from that of nonpublic figures.

First, it is important to clarify to what extant the English expression "privacy" corresponds to the definition of private life/ private sphere (Hungarian magánélet/magánszféra). In the present study, for stylistic reasons, these expressions are used as synonyms. It is essential to state that the two is not completely the same. The English expression "privacy" is usually translated to Hungarian as private sphere (magánszféra, privátszféra), private life (magánélet). However, finding a perfect Hungarian equivalent seems impossible, since the English expression implies more than just a person's physical private sphere, it also implies a one's feelings, human dignity, and the right to protection to one's personal data.

Warren and Brandeis, in their pivotal work, defines the essence of privacy as the absolute right "to be let alone". This formulation created a basis for a fundamental discourse during which many attempts have been made to redesign the definition.

Due to the almost infinite number of possible definitions the present study provides a subjective selection of the explanations to point out the wide range of interpretation of this eligibility. To close the chapter, I state my opinion by grasping the essential elements of these explanations.

In my view, it is appropriate to differentiate two groups of the attempts to define privacy. In the first group, there are the definitions, which do not consider privacy as a solid concept but capture several aspects of it.

Regarding this group, it is worth to mention Ken Gormley's, a Harvard Law School professor's work first, who has divided the definitions of private 
sphere into four groups. The first category includes definitions that view privacy as a major factor of humanness. He has categorized theories which consider privacy as the freedom of autonomy (i.e. decision making and expression). The third group based upon theoretical approaches that regards the flow of information about a person as essential part of privacy. The fourth category is made up of the theories that divide the right to privacy into various components ${ }^{3}$.

William A.Prosser's work is an important milestone on the subject of privacy, he published his study in 1960, in which like Cooley, he distinguished four cases, aiming at the possibility of vindication in a court case. The first group of cases contains intrusion into the plaintiff's private affairs, while the second involves disclosure of sensitive information regarding the plaintiff. The third case group involves publicity, which deceitfully characterizes the plaintiff to the general public, the fourth group includes the use of the plaintiff's name or appearance to the benefit of the respondent. According to Posser these cases are not closely related, although they all violate a part of the "privacy" they are supposed to be treated separately ${ }^{4}$.

Ferdinand Schoeman's work is also worth mentioning, he addressed the philosophical dimension of privacy and distinguished three segments of the private sphere. In Schoeman's view, privacy can be interpreted as a claim, title or right, that aims to allow the person to determine which personal information should be disclosed. On the other hand, it can mean control over an individual's private information, intimate aspects and the ability to determine who has access to them. Thirdly, it can be understood as a condition in which the access to the individual is restricted ${ }^{5}$.

To draw on the Hungarian legal literature, Fézer Tamás 's viewpoint could be highlighted. According to his views, there is and emotional and physical aspect of the protection of the private sphere ${ }^{6}$.

The second category includes the definitions, which regards privacy as a single, uniform concept.

\footnotetext{
3 Simon Éva op.cit.p. 33.

4 Paul M. Scwartz - Karl Nikolaus Peifer: Prosser's Privacy and the German right of personality: Are Four privacy torts better than one unitary concept?, in.: California Law Review, 2010/6., 1937.p.

5 JóRI András - Soós Andrea Klára: Adatvédelmi jog, Magyar és európai szabályozás, Budapest, 2016, 15-16.p.

Lásd. hozzá: Ferdinand D. Schoeman: Privacy: Philosophical Dimensions of Privacy: An Anthology, Cambridge University Press, Cambridge, 1984.

${ }^{6}$ FÉzer Tamás: A privátszféra polgári jogi védelmének alapkérdései, in.: Debreceni Jogi Mühely, 2014/1-2., 4.p. http://www.debrecenijogimuhely.hu/archivum/1_2_2014/a_privatszfera_ polgari_jogi_vedelmenek_alapkerdesei/ (Retrieved: 12 February 2020.)
} 
In this context, Thomas M. Cooley can be highlighted, who first used the phrase "the right to be let alone" in 1888 and from whose work Warren and Brandeis drew from; Cooley's starting point was the inviolability of the personality, he viewed the right to privacy as its completion ${ }^{7}$.

Clinton Rossiter, researcher at Cornell University, captured the essence of the concept in autonomy. According to his definition: "Privacy is a special kind of independence, which can be understood as an attempt to secure autonomy in at least a few personal and spiritual concerns, if necessary, in defiance of all the pressures of modern society"8.

Another prominent example is Alan Westin, Columbia University professor, he saw the essence of privacy in control over the flow of information related to the individual. According to his views, privacy is the right of individuals, groups, or institutions to determine for themselves when, how, and to what extent information about them is communicated to others 9 . Milton R. Konvitz came up with his definition of privacy at the same period of time; he defined private sphere as a "place" where one can be and can remain oneself $\mathrm{f}^{10}$.

Ruth Gavison, who has explored the nature of privacy in many of her studies, defines it as a limited accessibility to the individual. According to Gavison, the individual of whom no one has information, no one pays attention to and no one has physical access to has reached complete privacy ${ }^{11}$. This definition may sound somewhat idealistic, since this level of "anonymity", especially in the context of the digital world, seems impossible. Given today's technological context, the concept of invisibility on the Internet and "the right to be forgotten" is a very exciting question.

These entitlements are an important link to the right to privacy, as by tracking individuals' online activity various conclusions can be drawn from their social network, preference, habitual location, shopping habits, politics, or religious preferences. Summarizing all this data can be used to create

\footnotetext{
7 Dorothy J. GLANCY: The invention of the right to privacy, in.: Arizona Law Review, 1979/1. sz, 28.p.

8 SZÉKelY Iván - SOMODY Bernadette - SZABÓ Máté Dániel: Biztonság és magánélet, Az alkumodell megkérdőjelezése és meghaladása, in.: Replika, 2017/3, 15.p.

9 Mészáros János: Adatvédelem a XXI. században és az internet világában, PhD értekezés, Témavezető: Prof. Dr. Paczolay Péter, Szeged, 2017, 17.

10 Szabó Máté Dániel: Kísérlet a privacy fogalmának meghatározására a magyar jogrendszerfogalmaival, http://epa.oszk.hu/01900/01963/00013/pdf/infotars2005_05_02_044-054. pdf (Retrieved: 14 January 2020) 45.

11 See op.cit.p. 46.
} 
a profile that clearly affects privacy, so the prohibition of profiling means a crucial data protection guarantee.

There are numerous studies in the Hungarian legal literature concerning privacy, which focus only one aspect of private sphere. László Majtényi, for example, emphasized the nature of the eligibility through wide ranging literary comparisons ${ }^{12}$. Máté Dániel Szabó argues that privacy is the right of the individual to decide about one's faith, what one will do about oneself and the information about oneself ${ }^{13}$. László Székely describes privacy as the innermost space of an individual where one can express oneself without restrictions ${ }^{14}$. In the words of Attila Menyhárd, the right to privacy includes the right to physical, mental and social integrity ${ }^{15}$.

Considering conceptual questions, I would echo the position that do not regard privacy as a uniform concept. I took the view that privacy has both a material and psychic aspect. Privacy in the physical world refers to the tangible aspect of the private sphere, like the protection of private home or personal space. The protection of the private home is of crucial importance as it can be regarded as a core, a place where the legal subject can develop their personalities the most, without societal expectations or scrutiny. Personal space is not a permanent location, it serves as a shield from unauthorized, threatening influences.

Regarding the emotional side of the private sphere, personal data plays a prominent role, of which everyone can decide whether to disclose them or not. Confidentiality is vital as well as the protection of image and sound recording. Overall, it can be established, there is a psychic and physical aspect of privacy and both of their protection is of paramount importance. In my view, this conceptual definition points out and leads us to the question whether the right to privacy can be interpreted distinctly from other eligibilities.

I took the view, that violation of privacy can manifest in the violation of another personality right, therefore, we cannot speak of an independent, separate interpretation of these rights.

12 MaJTÉNYI László: Az információs szabadságjogok, adatvédelem és a közérdekü adatok nyilvánossága, CompLex Kiadó, Budapest, 2006, 46-55.

13 Szabó Máté Dániel op.cit.p.46.

14 SzÉKelY László: A magánszféra védelme az Ombudsmani gyakorlatban, 181. http://www.eltereader.hu/media/2018/04/Gorog_Menyhard_Koltay_Szemelyiseg_READER.pdf (Retrieved:2 May 2019).

15 MenYhÁRD Attila: A magánélethez való jog elméleti alapjai, in.: In Medias Res, 2014/2.sz., 55. http://www.eltereader.hu/media/2018/04/Gorog_Menyhard_Koltay_Szemelyiseg_READER.pdf (Retrieved: 2 May 2019). 


\section{Possible conceptual scope of public figures and the relevant judicial practice}

\subsection{Conceptual questions}

It is just as impossible to give an exact, universal definition of the notion of public figure as it is to do so with privacy, furthermore, giving an exact construction to it would not serve the exercise of rights. In a decision made in 1939, the Royal Curia of the Kingdom of Hungary stated that "satisfying gossipy curiosity is not in the public interest" ". Nowadays, the framework of the "gossipy curiosity" has fundamentally changed as a result of the advancements of the digital world and the interpretation of the personality rights has risen more question than ever before.

The current Civil Code defines the situation as a reason for exclusion of lawbreaking since the violation of the personality rights is made against a public figure; it requires judicial review. The law stipulates that the exercise of fundamental rights ensuring a free discussion of public affairs may limit the personality rights of public figures to an extent that is necessary and proportionate and is without violating human dignity; however, it shall not violate their private and family life and home ${ }^{17}$. Later, the law states that public figures shall be entitled to the same protection as non-public figures with regard to communications or conduct falling outside the scope of free discussion of public affairs ${ }^{18}$. Finally, it declares that activities and data in relation to the private or family life of public figures shall not qualify as public affairs ${ }^{19}$. These regulations were enacted as of 1 August 2019, in line with Act LIII of 2018. Present study will disclose this new type of regulation and the relating question in a separate chapter. In this chapter, it is crucial to fix that the Civil Code does not provide any guidelines to clarify the concept of public figures.

In legal regulations there can be found multiple definitions concerning public figures. One of them is Act No. III of 2003 On the Disclosure of the Secret Service Activities of the Communist Regime and on the Establishment of the Historical Archives of the Hungarian State Security, known commonly as the "agent law". The law views the exercise of public power as the main element in the notion of public figures. Based on

16 SARKADY Ildikó: A közszereplök személyiségvédelme a bírói gyakorlatban. http://www.mediakutato.hu/cikk/2006_03_osz/06_kozszereplok_szemelyisegvedelme (Retrieved: 26 November 2019).

\footnotetext{
17 Ptk. 2:44. § (1).

18 Ptk. 2:44. § (2).

19 Ptk. 2:44. § (3).
} 
Act III of 2003, public servant is any person, who exercises public power or was designated for a position entailing the exercise of public power and who forms or formed the political public opinion pursuant to his task $^{20}$. Act CXXXVI of 2007 on the Prevention and Combating of Money Laundering and Terrorist Financing views the concept from a different standpoint. The interpretive provisions state that "politically exposed persons" is natural persons residing in another country who are or have been entrusted with prominent public functions within one year before the carrying out of customer due diligence measures, and immediate family members, or persons known to be close associates, of such persons.

There are several formulations that require consideration in this legal norm and essentially it is the legal practice's duty to fill in this framework, but the law further clarifies who is considered as a politically exposed person. Such persons basically are natural persons entrusted with prominent public functions such as heads of the State, heads of the government, ministers, deputy ministers, secretaries of state, members of parliaments. Members of supreme courts and of constitutional courts or of other high-level judicial bodies, heads of courts of auditors, members of courts auditors, or of the boards of central banks also belong to this category. The regulation includes ambassadors, chargés d'eaffaires and high-ranking officers in the armed forces, with the ranks of chief officer or general officer, as well as, members of the administrative, management or supervisory bodies of Stateowned enterprises of majority control into this group ${ }^{21}$.

Both the agent law and the aforementioned law combating money laundering and terrorism are branch legislations. Obviously, they do not formulate universal definitions, these are only valid in the field they regulate.

The Constitutional Court has dealt with the nature of being a public actor. First, it discussed the nature of political public figures in Decision 36/1994 (VI. 24). AB, according to which public acting is expressions shaping the life of a narrower or wider part of society and influences the development of local or national relations ${ }^{22}$. This explanation has made it clear that the Constitutional Court captures the essence of the notion of public figure in some form of action.

In this respect, Levente Tattay's position can be emphasized, who considers the protection against public harm crucial for the sake of the purity of public life. He considers natural and legal persons as public figures who

\footnotetext{
20 Act III of $20031 . \S 13$.

21 Act CXXXVI of 2007,4.§ (1)-(2).

22 Decision 36/1994 (VI. 24.) AB.
} 
by their activities influence the life of a narrower or broader part of society, the development of local or national relations, and who are involved in a matter of public interest ${ }^{23}$.

Overall, it can be stated that law application has a key role since there is no generally accepted Civil Law definition of public figures.

The Regional Court of Pécs made an important finding in a case verdict, where it states that to decide whether an individual is a public figure or not position, official title, status or wider recognition for any reason should not be considered but specific life situation should ${ }^{24}$. Courts must decide on a case-by-case basis whether an individual should be regarded a public figure.

In my view, it is appropriate to broaden the notion of public figures. On the various image and video sharing portals, some users, who otherwise do not take on the classic role of public figures, have profiles with hundreds of thousands of followers and report on events that would otherwise belong to their private sphere. There is no universal standpoint on whether "internet celebrities" should be considered as public figures, it is for the judicial practice to clarify this question. As I see, it is justified to extend the notion of public figure to those who create profile pages with hundreds of thousands of followers on the Internet, since they are opinion leaders for a broad social group with their perspective, public lifestyle, opinion and by the products they advertise.

In the following, it is worth highlighting some case-law examples of domestic case-law and relevant ECHR case law, as well as an overview, in order to raise questions of the interpretation of the law on the protection of privacy.

\subsection{Relevant case-law}

In cases relating to the private life of public figures, the ECHR applies Article 8 and 10 of the European Convention on Human Rights. Article 8 declares the right to respect one's privacy, while Article 10 provides the right to freedom of expression. Regarding the verdicts, I examined these two competing eligibilities were in conflict. The baseline was, obviously, the case of von Hannover v. Germany ${ }^{25}$, since the ECHR declared relating

\footnotetext{
23 Tattay Levente: A közszereplők magánjogi személyiségvédelme, Magyar Jog, 2006/4, 228-233.

24 Regional Count of Pécs : Pf.20403/2010/4.

25 Von Hannover v Germany, no. 59320/00., 2004.június 24-i ítélet, Von Hannover v Germany (no.2.), no.40660/08. és 60641/08., 2012. február 7-i ítélet, Von Hannover v Germany (no. 3), no. $8772 / 10 ., 2013$. s.
} 
to images published by the press, thusly relating to privacy fundamental principles. Caroline von Hannover opened three court proceedings, she asked in each case that ECHR ban certain media outlets from publishing pictures of her. The newspaper articles complained of included snapshots taken of the princess in the context of her private, family life, such as portraying her in the patio of a restaurant having dinner with an actor or in the company of her children, so while performing everyday activities. The court's position was that the freedom of expression includes the right to disclose the pictures, the question in this case was whether the publication of the photos contributed to the free debate of public affairs and to the society's democratic function. The court ruled that the sole purpose of the of these pictures were to satisfy a gossip hungry social group and they did not contribute to the debate of general interest. Thus, the princess was right to refer to the infringement of her personality rights. In later proceedings opened by the princess the court refined its arguments and added new perspectives for consideration to balance between the freedom of expression and the right to privacy. One of the most important aspect is the extent to which the published images contribute the to debate of general interest, the fame of the person and the subject matter should also be considered. The circumstances in which the photographs were taken, and the behaviour of the person concerned in the past should be examined, as well as whether the image in question have already been published in any press organ.

The case of Krone Verlag Gmbh v Austria can also be highlighted ${ }^{26}$. The process was based on that the image of a politician named Posch, who was both a member of the national and European parliament and a tutor, was published multiple times by an Austrian newspaper, as the attachment of articles dealing with the politicians illegal asset management. As the court ruled a politician is unquestionably a public figure, hence Posch must bear the inherent consequences of his involvement in public affairs. Thus, the court found no substantial reason why the complainant should bar the publishing of the photographs. The court also pointed out that neither of the images led to the disclosure of the politician's private life, furthermore Posch's portrait and biography is available for everyone on the Austrian Parliament's website. According to the court's position such reporting cannot be limited in a democratically functioning society. This judgement raises interesting questions relating the protection of privacy, it is not interpreted independently, is alleged violation manifests in the image rights.

\footnotetext{
${ }_{26}$ Krone Verlag Gmbh \& Co. KG contra Austria. https://kuria-birosag.hu/hu/ejeb/krone-verlaggmbh-co-kg-beteti-tarsasag-ausztria-elleni-ugye-3431696.
} 
By examining these examples of ECHR judicial practice, it can be stated that it adopts functional approach, it is not based on the person in question but on the "function" he performs ${ }^{27}$. This definition is also consistent with the approach taken by the domestic courts, which interpreted the boundaries of privacy in relation with the right to images and the right to dignity, honour and reputation.

In a domestic lawsuit in 2016, the court had the task of interpreting the framework of public figures' privacy in connection with a Facebook $\operatorname{post}^{28}$. In a newspaper published by the defendant, a newspaper article entitled "Having a relationship with a man" was published concerning the plaintiff, a public figure. Images were also attached to the article, one showing the plaintiff and his partner, which was posted to Facebook by the plaintiff's partner also indicating in his post that they are in relationship. Following the publication of the article and the images, the plaintiff instituted proceedings against the defendant for infringement of his right to privacy. One of the main matters in the litigation was whether the content published by the plaintiff's partner was publicly disclosed or not. The plaintiff's position was that the article became available to wider audience without his consent resulting in his relationship status and homosexuality being revealed, although they were only intended to share this information with a group of 300-400 acquaintances.

The court dismissed the plaintiff's claim on the one hand, citing that the Facebook post in question had been publicly displayed on the profile page, so it was accessible to anyone, on the other hand, according to the 4 article of the Facebook's Disclaimer and Copyright, which acts as terms and conditions and accepted by all users upon registration, if users publish information with public setting they make it accessible to anyone to use it and to associate with users. Overall, it can be stated that the group of 300-400 acquaintances is not a narrow public, in case of such publication it cannot be barred that the content would be removed from this particular circle even by saving or forwarding. Against this background it can be established that Facebook posts shared with "public setting" do not belong to the protected domain of privacy.

A 2018 regional court verdict can also be noted on this subject ${ }^{29}$. Based on the state of its facts, a public figure was prosecuted which was covered by

\footnotetext{
27 Menyhárd Attila: A magánélethez való jog elméleti alapjai. http://media-tudomany.hu/ archivum/a-maganelethez-valo-jog-elmeleti-alapjai/.

28 Fővárosi Ítélőtábla: Pf. 21.053/2016/5.

29 BDT.2018.3847.
} 
great media interest. In connection with the procedure, a website published an article titled that after 72 hours of detention he looked for a partner smiling on the internet. The article also stated that the plaintiff searched for partner on bisexual and gay sites. As a result of the article the public figure has received several abusive private messages on social media sites. During this proceeding the Budapest-Capital Regional Court of Appeal ruled, that the right to privacy can only be restricted for public actor legal bodies, thus in case of politicians, in case of powerful public interest, if the intervention is in connection with the public figure's public appearance, public life, public ideology and actions taken to form public life. This court decision interprets the meaning of public figure's privacy clearly.

Studying the ECHR and domestic case can lead to the conclusion that there is no contradiction between the two. However, the law on the protection of privacy may have significant impact on the development of judicial practice, consequently an in-depth investigation is justified.

\section{Innovations of the Act LIII of 2018}

The preamble of the act on the protection of privacy ${ }^{30}$ declares that the right to privacy is indispensable for the fulfilment of human life since it delimits the untouchable realm of human personality. The law also states that the protection of privacy should extend to harassments both in the physical world and on the internet and the dignity of the individual and rights to private life should also be secured bot in the real and online world. The regulation also declares that the right to privacy should also be respected during the free debating of public affairs; therefore, the free debating of the issues of public life should not result in impairing private and family life or one's home. Public figures are also entitled to the protection of private life and the tranquillity of home.

The law on the protection of privacy declares that everyone shall have the right to privacy and identifies it as a part of the right to the free development of one's own personality and clarifies the possibility of its restriction with rules set out in the Fundamental $\mathrm{Law}^{31}$. Then it names the "sub-areas" of the right to privacy, the protection of his family life $^{32}$, the right to respect for family life ${ }^{33}$ and the right to respect for communications. Of these, the respect for communications can be violated

\footnotetext{
30 Act LIII of 2018.

31 Act LIII of $20182 . \S(1)-(2)$.

32 Act LIII of 2018 9.§.

33 Act LIII of 2018 10.§.
} 
the easiest in the online space, in this respect the law on the right to privacy states that individuals should enjoy enhanced protection against all forms of harassment on the internet.

Regarding the legal consequences of the violation of the right to privacy the law on the protection of privacy and the Civil Code imposes the subjective and objective sanctions as in the event of personality right violations ${ }^{34}$.

Often emerges the issue in relation with the new regulation that if no information concerning public figures' lives should be disclosed then they do not have to tolerate more than an "average" legal entity, despite the great public interest ${ }^{35}$. The regulation, essentially, exclude the ECHR's interpretative principle's application, which states that in justifiable cases information about public figures' private life can be disclosed. A good example is the case of Couderc and Hachette Filipacchi Associés v. France ${ }^{36}$, which was brought before the ECHR, the court ruled that it was lawful to publish an article about Prince Albert's child born out of wedlock. The court argued that although, the birth is an intimate event, it does not exclusively belong to the private sphere of the people concerned, but also has a public dimension, as it involves an official statement(registry) and the establishment of the legal relationship between child and parent. Given the peculiar system of the Principality of Monaco, there was an undeniable public interest, at least amongst the subjects of the Principality, in the fact that Prince Albert, who at that time was known to be single and child free, has a son. This development would have had an impact on succession and the budget; by marriage, although it was unlikely, the issue of legitimacy could have risen. The article touched upon the issue of the consequences of succession, the Court argued that for an article to contribute the public discourse it does not necessarily have to discuss the matter in the entire article.

Still, under the current Hungarian law, such a decision would not be possible and would not be lawful to disclose information of the private lives of public figures. Nevertheless, it aids the court by giving possibility of a stricter interpretation of the question, when the violation of the right to images and sound recordings, the misuse of personal data or the breach of the right to human dignity are considered also as the violation of the right to privacy $^{37}$.

\footnotetext{
34 Act LIII of 2018 12-14.§.

35 Barzó Tímea: A közéleti szereplők és a magánélethez füződő jog. https://docplayer.hu/ 111512315-A-kozeleti-szereplok-es-a-maganelethez-fuzodo-jog-public-figures-and-the-right-toprivacy.html (Retrieved: 11 January 2020).

36 http://epa.oszk.hu/02300/02334/00070/pdf/EPA02334_fundamentum_2016_01_115-131.pdf.

37 Barzó op.cit.
} 
Overall, it can be concluded that the Act LIII of 2018 repeats and at some points supplements the provisions of the Fundamental Law, Civil Code and the Act on information self-determination and freedom of information. The interpretation of this legislation is the court's future duty.

\section{CONCLUSIONS}

All in all, it can be stated that the interpretation of public figures' right to privacy raises multiple question of legal interpretation and law application. As a matter of fact, we are dealing with two vaguely defined concept of law.

Hence, I find important the ideological review of the right to privacy and the notion of public figures. In this respect, I highlighted the difficulties of privacy's independent interpretation. Then, I emphasized my view that privacy is not a uniform notion concept but on that is made up of several part-eligibilities. I find justifiable to expand the circle of public figures.

I also found it important to introduce the domestic and ECHR case-law. I found it essential to present the novelties of the relating regulation. Its interpretation is the duty of the judicial practice, it is their responsibility to decide how wide they open the door for the intrusive curiosity.

\section{SUMMARY}

In the recent study, I have used several research methods. The main guidelines were analytical and descriptive methods. Through the ideological review I developed my own position on the nature of privacy. Later, by exploring the domestic and ECHR case I drew forward-looking conclusions. The study comprehensively examined the issue of public figures' privacy. In this respect I emphasized the law on the protection of privacy, which awaits judicial interpretation. To explore this, further research seems necessary.

\section{REFERENCES}

1. Peter Bertus-Barcza: Az első Kodak fényképezőgép. https://ng.hu/kultura/2006/09/04/az_elso_kodak_fenykepezogep/.

2. Simon Éva: Egy XIX. századi tanulmány margójára, 33-36. https://infonia.hu/digitalis_folyoirat/2005_2/2005_2_simon_eva.pdF.

3. Paul M. Scwartz - Karl Nikolaus PeIFER: Prosser's Privacy and the german right of personality: Are Four privacy torts better than one unitary concept?, in.: California Law Reviwev, 2010/6, 1937.

4. JóRI András - Soós Andrea Klára: Adatvédelmi jog, Magyar és európai szabályozás, Budapest, 2016, 15-16.

5. FÉzer Tamás: A privátszféra polgári jogi védelmének alapkérdései, in.: Debreceni Jogi Mühely, 2014/1-2, 4. 
6. Dorothy J. Glancy: The invention of the right to privacy, in.: Arizona Law Review, 1979/1.sz., 25.

7. SzÉKely Iván - Somody Bernadette - SzaBó Máté Dániel: Biztonság és magánélet, Az alkumodell megkérdőjelezése és meghaladása, in.: Replika, 2017/3.sz., 15 .

8. MészÁros János: Adatvédelem a XXI. században és az internet világában, PhD értekezés, Témavezető: Prof. Dr. Paczolay Péter, Szeged, 2017, 17.

9. Szabó Máté Dániel: Kísérlet a privacy fogalmának meghatározására a magyar jogrendszer fogalmaival, 45-50, http://epa.oszk.hu/01900/01963/ 00013/pdf/infotars2005_05_02_044054.pdf.

10. MAJTÉNYI László: Az információs szabadságjogok, adatvédelem és a közérdekủ adatok nyilvánossága, CompLex Kiadó, Budapest, 2006, 46-55.

11. SzÉKeLY László: A magánszféra védelme az Ombudsmani gyakorlatban, 181. http://www.eltereader.hu/media/2018/04/Gorog_Menyhard_Koltay_ Szemelyiseg_READER.pdf.

12. MenYHÁRD Attila: A magánélethez való jog elméleti alapjai, in.: In Medias Res, 2014/2.sz., 55. http://www.eltereader.hu/media/2018/04/ Gorog_Menyhard_Koltay_Szemelyiseg_READER.pdf.

13. SARKADYIldikó:Aközszereplőkszemélyiségvédelmeabíróigyakorlatban. http://www.mediakutato.hu/cikk/2006_03_osz/06_kozszereplok_ szemelyisegve.

14. TATTAY Levente: A közszereplök magánjogi személyiségvédelme, Magyar Jog, 2006/4, 228-233.

15. BARzó Tímea: A közéleti szereplők és a magánélethez füződő jog. https://docplayer.hu/111512315-A-kozeleti-szereplok-es-a-maganelethezfuzodo-jog-public-figures-and-the-right-to-privacy.html.

\section{Information about author:}

Halász Csenge, PhD Student

Ferenc Deák Doctoral School of Law University of Miskolc, Hungary

DOI https://doi.org/10.30525/978-9934-588-43-3/1.3 